\section{Microbial Reduction by Two Chemical-Mechanical Protocols in Primary Teeth with Pulp Necrosis and Periradicular Lesion - An In Vivo Study}

Thaisa Cezária Triches ${ }^{1}$, Luciene Cristina de Figueiredo ${ }^{2}$, Magda Feres ${ }^{2}$, Sérgio Fernando Torres de Freitas ${ }^{3}$, Gláucia Santos Zimmermann ${ }^{4}$, Mabel Mariela Rodríguez Cordeiro ${ }^{5}$

\begin{abstract}
The objective of this study was to determine the efficacy of chemical-mechanical procedures of two endodontic protocols for septic content reduction of root canals from primary teeth with pulp necrosis and periradicular lesion. Twenty-four primary root canals with pulp necrosis and periradicular lesion were divided into two treatment groups $(n=12)$ : multiple-visit and single-visit protocols. Samples were collected using sterile paper points before and after endodontic cleaning followed by microbiological identification through checkerboard DNA-DNA hybridization. Statistical analysis was performed using Proportion Test for score $=0$ comparing the findings before and after treatment for each group (Wilcoxon's test) as well as the differences in scores between protocols (Mann-Whitney's test) $(p<0.05)$. Data were expressed as prevalence (presence or absence) and estimate of the average count $\left(\times 10^{5}\right.$ cells) of each species. Differences in proportions of score $=0$ prior to treatment were non-significant $(p=0.415)$, demonstrating equivalence between groups. A significant increase in score $=0$ was detected after treatment for both groups $(p<0.0001)$. Single-visit protocol achieved a significantly greater reduction in mean scoring following endodontic treatment $(p=0.024)$. Both protocols were capable of significantly reducing septic content in root canals of primary teeth with periradicular lesion. Moreover, singlevisit protocol showed greater efficacy in reducing endodontic infection.
\end{abstract}

\author{
'Department of Dentistry, UFSC \\ - Federal University of Santa \\ Catarina, Florianópolis, SC, Brazil \\ ${ }^{2}$ Department of Periodontology, \\ Dental Research Division, Guarulhos \\ University, Guarulhos, SP, Brazil \\ ${ }^{3}$ Department of Public Health, \\ UFSC - Federal University of Santa \\ Catarina, Florianópolis, SC, Brazil \\ ${ }^{4}$ Department of Periodontology, \\ UFSC - Federal University of Santa \\ Catarina, Florianópolis, SC, Brazil \\ ${ }^{5}$ Department of Morphological \\ Sciences, UFSC - Federal \\ University of Santa Catarina, \\ Florianópolis, SC, Brazil
}

Correspondence: Dra. Thaisa Cezária Triches, Rua Paulo Furtado Lucena, n. 101, Centro, 85.990-000 Terra Roxa, PR, Brasil. Tel: +55-44-36451305. e-mail: ttriches@gmail.com

Key Words: DNA probes, infection, tooth deciduous, dental pulp necrosis, endodontics.

\section{Introduction}

The aim of root canal treatment (RCT) is to maintain teeth with compromised pulp in the oral cavity in order to avoid more complex, aggressive treatments (1). This reaches more importance in children, as the early loss of primary teeth can compromise the development of the stomatognathic system and the installation of the permanent dentition as well as lead to emotional, psychological and behavioral problems (2).

The success of RCT depends on a number of factors, being the most important the reduction and/or elimination of bacterial infection in the root canal system, which can be largely achieved through the chemical-mechanical treatment of the root canal $(3,4)$.

Although the chemical-mechanical treatment of infected root canals is effective in reducing root canal infection, viable microorganisms are often isolated after treatment. Some authors have reported the importance of cleaning using adequate chemical substances and/or instruments to favor better pharmacological action of the drugs used in intracanal dressings and/or filling, thereby offering conditions for a faster, more organized organic response. Both multiple- and single-visit protocols are currently used to reduce microbial content in root canals of primary teeth $(5,6)$.

The greatest barriers to successful endodontic treatment of primary teeth with pulp necrosis are derived in most cases from the method of root canal preparation (5). However, there is yet no consensus on the most favorable protocol. Few studies have been performed to determine what endodontic technique offers the greatest efficacy regarding reduction of infection in primary teeth (7-9). Moreover, only one of them has employed the checkerboard DNA-DNA hybridization molecular detection method (9). Thus, the aim of this study was to determine the efficacy of chemical-mechanical procedures of a multiple-visit (MVP) and a single-visit protocol (SVP), in reducing microbial content of root canals of primary teeth with pulp necrosis and periradicular lesion, using the checkerboard DNA-DNA hybridization molecular detection method.

\section{Material and Methods}

\section{Ethical Considerations}

This research was conducted ethically in accordance with the Declaration of Helsinki. After research project approval by the Ethics Committee for Research on Human Subjects (number 096/09 FR255814), 8 children (4 males and 4 females), with mean age of 6 years, treated at the 
Pediatric Dentistry Clinic were included in the study, following signature of the informed consent form by patient's legal guardian.

Initial sample was calculated from Silva et al. (3) using the following parameters: confidence interval of 95\%; variance equal to $3.7 \times 10^{3}$ colony-forming units (CFU); and, accuracy of $2.1 \times 10^{3} \mathrm{CFU}$, resulting in 12 specimens.

A total of 24 root canals of eight multiradicular primary teeth (with 3 canals each one) were randomly divided into two groups ( $n=12)$ : MVP and SVP. The choice of these two protocols was based on the fact that these are protocols used and taught in several Dental Schools of Brazil for the treatment of primary teeth with compromised pulp tissue.

To be included in the study, children could not have any systemic disease or impairment or have made use of antibiotic and/or antimicrobial agents in the previous three months. Primary tooth should have pulp involvement due to the advance of carious lesion and diagnosis of pulp necrosis with associated periradicular lesion (confirmed by periapical radiography), with or without draining sinus tract. Tooth should also have indication for endodontic treatment and proper conditions to be adequately isolated and restored.

All patients received not only endodontic treatment and definitive restoration but also all other dental needs in order to reestablish patient's oral health and were included in a longitudinal clinical and radiographic follow up.

\section{Chemical-Mechanical Treatment}

Multiple-visit protocol (MVP) (6): This protocol was performed in 3 visits, starting with a previous medication with diluted formocresol (1:5) for 7 days, to neutralize septic content of the root canal. Emptying and shaping of the canals were performed in the second appointment, using endodontic files up to size 35 or 40 and irrigation with $1 \%$ sodium hypochlorite. Third appointment consisted of root canal filling with zinc oxide and eugenol cement.

Single-visit protocol (SVP) (5): Root canals were emptied and cleaned using only two large-caliber files, following the first one, and irrigation with $0.5 \% \mathrm{NaOCl}$ buffered with sodium bicarbonate and ENDO-C-PREP (10\% urea peroxide, 15\% Tween 80 and 75\% Carbowax). Final irrigation was performed with Tergensol. Root canal filling was performed with iodoform paste.

\section{Sample Collection and Treatment}

All steps of both protocols as well as collection and preparation of the root canal samples were performed by a single operator. After diagnosis and anesthesia, antisepsis of the oral cavity was performed using $0.12 \%$ chlorhexidine digluconate for one minute. Following absolute isolation with rubber dam, further disinfection of the tooth surface and surrounding areas was performed twice with 1\% chlorhexidine digluconate $(9,10)$ for three minutes each time (10). After carious tissue removal, complete access to the pulp chamber and root canal was obtained and all the aforementioned disinfection maneuvers were repeated.

Samples were collected with three \#15 sterile paper points, absorbing the content from each canal during one minute in two different moments: first, inserting the paper point up to the radiographic apparent tooth length prior to treatment and, second, up to the working length following chemical-mechanical maneuvers. The first sampling aimed to determine the initial microbial profile while the second sought to identify, count, and determine the percentage of remaining microorganisms following treatment. Paper points were removed from the root canal and immediately placed in Eppendorf tubes containing $0.15 \mathrm{~mL}$ of TE buffer solution ( $\mathrm{pH}$ 7.6). One hundred $\mu \mathrm{L}$ of $0.5 \mathrm{M} \mathrm{NaOH}$ was added to each tube and the samples were dispersed using a vortex mixer.

Evaluation was performed using checkerboard DNADNA hybridization for the identification of 40 different bacteria (Table 1).

\section{Checkerboard DNA-DNA Hybridization}

Counts of 40 bacterial species were determined in each sample, using the checkerboard DNA-DNA hybridization technique (11). The microbiological analysis was entirely performed at the Laboratory of Microbiology. The samples were boiled for $10 \mathrm{~min}$. and neutralized using $0.8 \mathrm{~mL}$ of $5 \mathrm{M}$ ammonium acetate. The released DNA was then placed into the extended slots of a Minislot 30 apparatus (Immunetics ${ }^{\circledast}$, Cambridge, MA, USA), concentrated on a $15 \times 15 \mathrm{~cm}$ positively charged nylon membrane (Boehringer Mannheim ${ }^{\oplus}$, Indianapolis, IN, USA) and fixed to the membrane by baking it at $120^{\circ} \mathrm{C}$ for $20 \mathrm{~min}$. The membrane was placed in a Miniblotter 45 (Immunetics ${ }^{\circledR}$ ) with the lanes of DNA at $90^{\circ}$ to the lanes of the device. Digoxigeninlabeled whole genomic DNA probes for 40 bacterial species were hybridized in individual lanes of the Miniblotter. After hybridization, the membranes were washed at high stringency and the DNA probes were detected using the antibody to digoxigenin conjugated with alkaline phosphatase and chemiluminescence detection. The last two lanes in each run contained standards at concentrations of $10^{5}$ and $10^{6}$ cells of each species. Signals were evaluated visually by comparison with the standards at $10^{5}$ and $10^{6}$ bacterial cells for the test species on the same membrane by a calibrated examiner. They were recorded as: $0-$ not detected; $1-<10^{5}$ cells; $2-\sim 10^{5}$ cells; $3-10^{5}-10^{6}$ cells; 4$\sim 10^{6}$ cells; or $5->10^{6}$ cells.

\section{Statistical Analysis}

Data analysis was performed using Proportion Test for 
the comparison of initial scores $=0$ between groups and the effectiveness of the protocols based on scores $=0$. Data were also expressed in prevalence (presence or absence) and an estimate of the average count ( $\times 10^{5}$ cells) of each species. Wilcoxon's test was used to compare all scores before and after treatment in each group separately. MannWhitney's test was used for analysis of differences between groups. The level of significance used was $\mathrm{p}<0.05$.

\section{Results}

\section{Initial Infection}

Table 2 displays the number of observations per score in MVP and SVP before and after treatment. In the assessment of the initial amount of bacterial cells, the comparison of score $=0$ in MVP and SVP revealed no statistically significant differences ( $p=0.415)$ demonstrating that both groups were equivalent.

The results of the comparison of the proportions of all scores between the two initial groups also showed that the observed differences at baseline were not significant $(p=0.1492)$, i.e., there was a similar condition of initial scores in both groups.

\section{Microbial Content Reduction}

Table 2 shows the results of the comparison of the total number of score $=0$ before and after treatment. There was a significantly higher percentage of score $=0$ following root canal cleaning $(p<0.0001)$ for both groups, demonstrating that both protocols were effective.

The comparison of total scores between the moments before and after for each protocol showed that both groups had higher bacterial concentration prior to endodontic instrumentation $(p<0.0001)$.

\section{Microbial Content Before and After Treatment}

There were found statistically significant differences in the mean scoring before and after treatment for both groups, with substantially lower scores following treatment [MVP: $t=6.58$ $(p<0.0001) ;$ SVP: $t=10.31(p<0.0001)]$ (Table 2).

In Figures 1 and 2 can be observed, respectively, the approximated average $\left(\times 10^{5}\right.$ cells) of each bacterial species detected in the moments before and after treatment for MVP and SVP techniques.

Comparing all the scores for each group after instrumentation, it was found that both techniques were effective in reducing bacterial counting $(p=0.1253)$.
Table 1. Bacterial species used to prepare the genomic DNA probes

\begin{tabular}{|c|c|}
\hline Bacterial species & Strain \\
\hline Actinomyces gerencseriae & ATCC 23860 \\
\hline Actinomyces israelii & ATCC 12102 \\
\hline Actinomyces naeslundii I & ATCC 12104 \\
\hline Actinomyces odontolyticus I & ATCC 17929 \\
\hline Aggregatibacter actinomycetemcomitans serotypes a & ATCC 43718 \\
\hline Campylobacter gracilis & ATCC 33236 (1084) \\
\hline Campylobacter rectus & ATCC 33238 (371) \\
\hline Campylobacter showae & ATCC 51146 \\
\hline Capnocytophaga gingivalis & ATCC 33624 (27) \\
\hline Capnocytophaga ochracea & ATCC 33596 (25) \\
\hline Capnocytophaga sputigena & ATCC 33612 (4) \\
\hline Eikenella corrodens & ATCC 23834 \\
\hline Enterococcus faecalis & ATCC 29212 \\
\hline Enterococcus faecium & ATCC 6569 \\
\hline Enterococcus hirae & ATCC 10541 \\
\hline Eubacterium nodatum & ATCC 33099 \\
\hline Eubacterium saburreum & ATCC 33271 \\
\hline Fusobacterium nucleatum sp. nucleatum & ATCC 25586 \\
\hline Fusobacterium nucleatum sp. polymorphum & ATCC 10953 \\
\hline Fusobacterium nucleatum sp. vincentii & ATCC 49256 \\
\hline Fusobacterium periodonticum & ATCC 33693 \\
\hline Gemella morbillorum & ATCC 27824 \\
\hline Neisseria mucosa & ATCC 19696 \\
\hline Parvimonas micra & ATCC 33270 \\
\hline Porphyromonas endodontalis & ATCC 35406 \\
\hline Porphyromonas gingivalis & ATCC 33277 \\
\hline Prevotella intermedia & ATCC 25611 \\
\hline Prevotella melaninogenica & ATCC 25845 \\
\hline Prevotella nigrescens & ATCC 33563 \\
\hline Propionybacterium acnes I & ATCC 11827 \\
\hline Selenomonas noxia & ATCC 43541 \\
\hline Streptococcus constellatus & ATCC 27823 (M32b) \\
\hline Streptococcus gordonii & ATCC 10558 \\
\hline Streptococcus intermedius & ATCC 27335 \\
\hline Streptococcus mitis & ATCC 49456 \\
\hline Streptococcus oralis & ATCC 35037 \\
\hline Tannerella forsythia & ATCC 43037 (338) \\
\hline Treponema denticola & "B1 \\
\hline Treponema socranskii & ATCC D40DR2 \\
\hline Veillonella parvula & ATCC 10790 \\
\hline
\end{tabular}

*Strain B1 (Forsyth Institute, Boston, MS, USA). ATCC=American Type Culture Collection (Rockville, MD, USA). 


\section{Comparison of Microbial Reduction Between Protocols}

It was found a greater reduction of mean scoring in SVP (mean: 0.631) compared to MVP (mean: 0.398), with a statistically significant difference between groups $(p=0.024)$.

Table 2. Number and percentage of observations per score before and after multiple-visit and single-visit protocols

\begin{tabular}{|c|c|c|c|c|c|c|c|c|}
\hline \multirow{2}{*}{ Score } & \multicolumn{2}{|c|}{ Before MVP } & \multicolumn{2}{|c|}{ Before SVP } & \multicolumn{2}{|c|}{ After MVP } & \multicolumn{2}{|c|}{ After SVP } \\
\hline & $\mathrm{n}$ & $\%$ & $\mathrm{n}$ & $\%$ & $\mathrm{~N}$ & $\%$ & $\mathrm{~N}$ & $\%$ \\
\hline 0 & 252 & 52.5 & 236 & 49.2 & 337 & 70.2 & 358 & 74.6 \\
\hline 1 & 69 & 14.4 & 59 & 12.3 & 43 & 9.0 & 41 & 8.5 \\
\hline 2 & 81 & 16.9 & 90 & 18.8 & 67 & 14.0 & 51 & 10.6 \\
\hline 3 & 71 & 14.8 & 78 & 16.2 & 27 & 5.6 & 24 & 5.0 \\
\hline 4 & 6 & 1.2 & 16 & 3.3 & 6 & 1.2 & 6 & 1.3 \\
\hline 5 & 1 & 0.2 & 1 & 0.2 & 0 & 0.0 & 0 & 0.0 \\
\hline Total & 480 & 100.0 & 480 & 100.0 & 480 & 100.0 & 480 & 100.0 \\
\hline
\end{tabular}

\section{Discussion}

Sample consisted of root canals instead of dental elements. Each root canal was considered an independent event (10). Therefore, the use of dental elements as units would lead to distortion of results (10). All aspects were observed in this study: 1 out of the 8 teeth had both pulp vitality and pulp necrosis in its root canals; 7 teeth showed at least 11 different bacterium species among their root canals; and, 6 teeth had 30\% less bacteria between root canals.

To our knowledge, this is the first in vivo study to assess the effectiveness of chemical-mechanical procedures of two different root canal treatment protocols for primary teeth. The few studies performed on primary teeth analyzed the profile of the root canal microbiota $(3,10,12,13)$, the effect of medications in intracanal dressings and/ or fillings $(5,7,9,14-16)$, or individual endodontic techniques $(7,9)$.

According to Peters et al. (17), although the complete elimination of microorganisms cannot

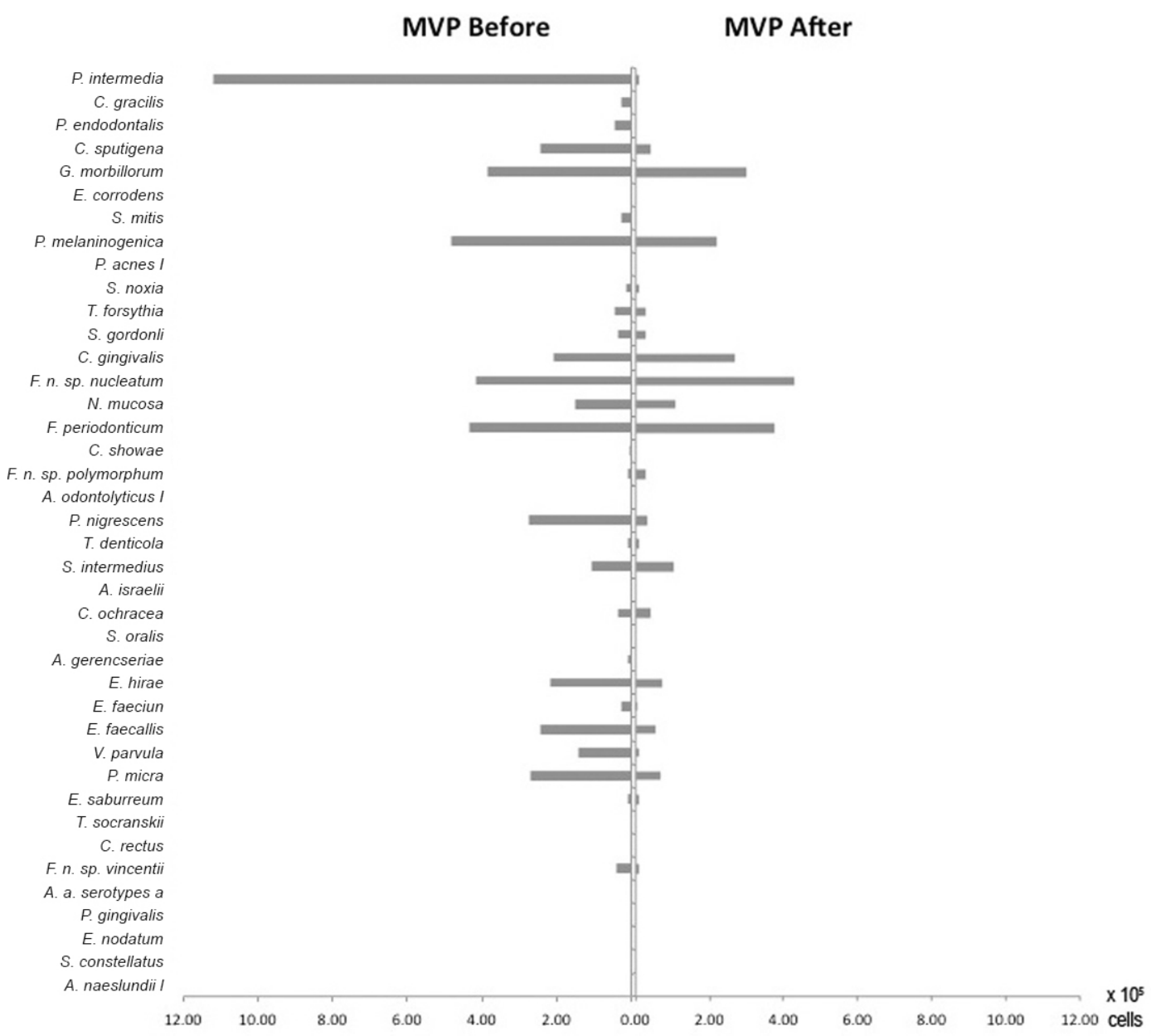

Figure 1. Approximated average ( $\times 10^{5}$ cells) of each bacterial species detected in the moment before treatment for the multiple-visit protocol (MVP). 
be achieved through chemical-mechanical maneuvers, the residual flora can be reduced in two visits of root canal treatment. Thus, rather than trusting in intracanal dressings, a second careful cleaning of the canal is required to eliminate residual microbiological content.

Although the remaining infection may be eliminated and/or controlled by intracanal dressings, a lesser infection rate following cleaning and modeling leads to greater effectiveness of these medications. In our study, the SVP proved to be more effective than the MVP.

From the 40 probes used, 28 (70\%) were identified on the initial sample collection in MVP and $35(87.5 \%)$ in SVP. These profiles diminished after treatment to $23(57.5 \%)$ and $28(70 \%)$, respectively. Ruviére et al. (13) used 34 probes and found $82.3 \%$ (28 probes) with positive signal. Ito et al. (9) used 35 probes, from which 31 (88.5\%) were positive on the first collection and $13(37.1 \%)$ on the second.

Our study detected scores from 0 to 5 , which corroborates the findings reported by Ito et al. (9). However, Ruviére et al. (13) only found scores from 0 to 3 . It should be pointed out that a score $=0$ does not necessarily mean the absence of bacteria. This may either signify that bacteria are present at a concentration below the detection threshold of the method or that these bacteria are really absent.

Chemical-mechanical procedures of the MVP for primary teeth follow the same biological principles that govern root canal treatment of permanent teeth (i.e., cleaning and modeling) which, in comparison to the SVP, may lead to greater wear of the canal walls, weakening the structure of the root and increasing the risk of perforation. On the other hand, the aim of the SVP is merely cleaning and removal of the greatest possible amount of necrotized tissue and infection, without shaping.

This study demonstrated that both protocols significantly increased the proportion of score $=0$ and, then, can be considered effective. However, SVP achieved a significantly greater reduction of contamination (74.6\%) in comparison to the MVP (70.2\%). This may be explained by the differences in the methodological steps of each protocol.

Although both protocols demonstrated capacity to reduce mean scoring, SVP showed greater ability. This

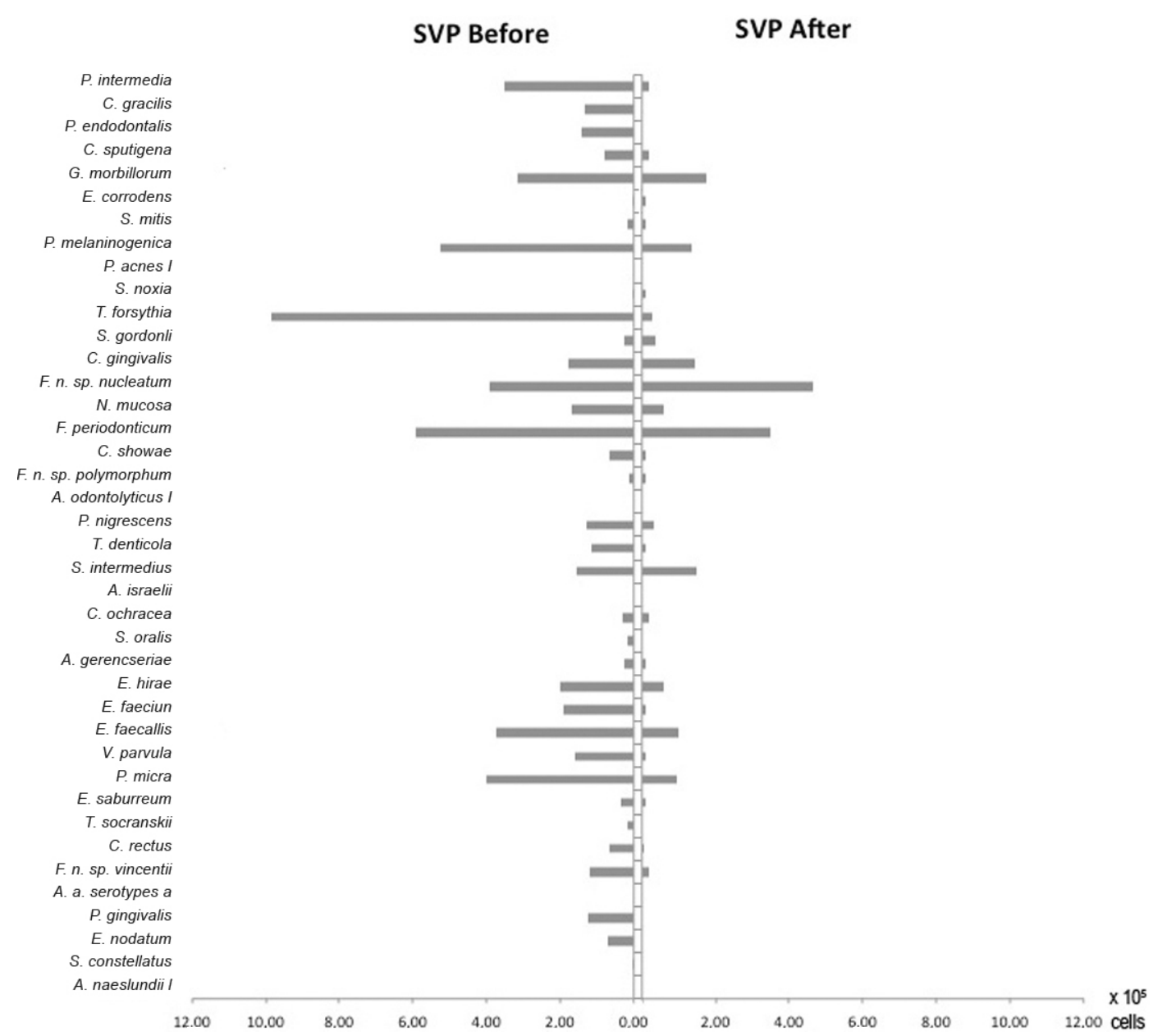

Figure 2. Approximated average ( $\times 10^{5}$ cells) of each bacterial species detected in the moment before treatment for the single-visit protocol (SVP). 
may have been influenced by higher scores in the initial evaluation, which may have led to a more frequent reduction to score $=0$ in SVP. Such a possibility must be specifically approached, as the proposed study design did not completely control this aspect and was not planned for this.

Considering working time for root canal treatment in pediatric dentistry, SVP is advantageous since its technical steps are simple and aim merely at cleaning. In contrast, MVP is performed in 3-5 sessions, each involving anesthesia, absolute isolation, and temporary crown sealing, which can be lost between visits, thereby requiring repetition of all the initial procedures. As MVP involves a greater use of files, it requires a more precise root canal length establishment and therefore at least four radiographs are taken (initial, tooth length measurement, filling, and final). It is of note that the tooth length measurement radiography may need to be repeated due to flaws. In SVP, only two radiographs are required (initial and final), resulting in lesser exposure of the child (and sometimes his/her parent/guardian) to radiation as well as better patient's behavior, as many children feel discomfort during radiograph taking. Thus, the fewer number of visits and radiographs are advantages $\vec{s}$ to be weighed in the choice of the root canal treatment protocol for primary teeth.

Tooth length establishment in MVP is similar to that executed for permanent teeth and is safer because it is more discerning for the confirmation of the tooth length. Moreover, using radiographic points of reference, it provides greater security in the determination of the working length for exploration as well as the adequate length for filling (6). Tooth length measurement in SVP does not securely provide adequate lengths for chemical-mechanical treatment and filling. If apical leakage occurs, the crown of the permanent successor may be stained by the iodoform paste used as filler. However, literature reports that the leakage assists the healing process, especially in the presence of draining sinus tract (5).

Gomes et al. (8) microbiologically assessed the effectiveness of chemical-mechanical procedures and components of the iodoform paste for the removal of necrotized pulp from primary teeth. Positive cultures were obtained both before and after treatment, but the intensity of infection was reduced from strong at the initial assessment to moderate following treatment. After one week with the paste dressing, 48\% of the samples had negative cultures and the 52\% positive cultures were of mild infection.

MVP have been assessed under different aspects $(18,19)$, yet not concerning the capacity of reducing microbial content. Our group is currently assessing the effect of intracanal dressing of the MVP on the reduction of the remaining endodontic infection.

In conclusion, chemical-mechanical procedures of both protocols of endodontic treatment for primary teeth proved to be capable of significantly reducing the septic content. Therefore, the dentist should choose the technique to be used according to personal preference and/or characteristics of the case.

\section{Resumo}

0 objetivo deste estudo foi determinar a eficácia das manobras quimicomecânicas de dois protocolos endodônticos, na redução do conteúdo séptico de canais radiculares de dentes decíduos com polpa necrosada e lesão perirradicular. Vinte e quatro canais radiculares decíduos com necrose pulpar e lesão perirradicular foram divididos em dois grupos de tratamento $(n=12)$ : multisessões e sessão única. Amostras foram coletadas usando pontas de papel estéreis, antes e após a limpeza endodôntica, seguido de identificação microbiológica por hibridização DNA-DNA checkerboard. A análise estatistica foi realizada usando teste de proporções para escore $=0$, comparando os achados antes e após tratamento para cada grupo (teste de Wilcoxon) e as diferenças dos escores entre os protocolos (teste de Mann-Whitney) $(p<0,05)$. Os dados foram expressos em prevalência (presença ou ausência) e contagem média ( $\times 10^{5}$ células) de cada espécie. As diferenças nas proporções de escore $=0$ antes do tratamento não foram significativas $(p=0,415)$, mostrando equivalência entre os grupos. Um aumento significativo de escore $=0$ foi detectado após o tratamento para ambos os grupos $(p<0,0001)$. 0 protocolo de sessão única mostrou uma redução significativamente maior dos escores médios após o tratamento endodôntico $(p=0,024)$. Ambos os protocolos são capazes de reduzir significativamente o conteúdo séptico de canais radiculares de dentes decíduos com lesão perirradicular. Entretanto, o protocolo de sessão única mostrou uma maior eficácia na redução da infecção endodôntica.

\section{Acknowledgements}

The authors thank Ana Paula Beltrame and Marcos Ximenes Filho for their contributions to the development of the clinical part of this study. Authors also acknowledge the support received from Coordenação de Aperfeiçoamento de Pessoal de Nivel Superior - CAPES (Brazilian Government) for the pursuit of the studies that were presented in this manuscript.

\section{References}

1. Siqueira Jr JF, Rôças IN. Clinical implications and microbiology of bacterial persistence after treatment procedures. J Endod 2008;34:1291-1301.

2. Cordeiro MMR, Rocha MJC. The effects of periradicular inflammation and infection on a primary tooth and permanent successor. J Clin Pediatr Dent 2005;29:193-200.

3. Silva $L A B$, Nelson-Filho P, Faria G, Sousa-Gugelmin MCM, Ito IY. Bacterial profile in primary teeth with necrotic pulp and periapical lesions. Braz Dent J 2006;17:144-148.

4. Souza CAS, Teles RP, Souto R, Chaves MAE, Colombo APV. Endodontic therapy associated with calcium hydroxide as an intracanal dressing: microbiologic evaluation by the checkerboard DNA-DNA hybridization technique. J Endod 2005;31:79-83.

5. Guedes-Pinto AC, Paiva JG, Bozzola JR. Endodontic treatment of deciduous teeth with nonvital pulp. Rev Ass Paul Cirurg Dent 1981;35:240-245.

6. Rocha MJC. Endodontic treatment in decayed deciduous teeth. In: Livro Anual do Grupo de Professores de Ortodontia e Odontopediatria. Anais 10. Belo Horizonte: Furmac; 2001. p 28-30.

7. Faria G, Nelson-Filho P, Freitas AC, Assed S, Ito IY. Antibacterial effect of root canal preparation and calcium hydroxide paste (Calen) intracanal dressing in primary teeth with apical periodontitis. J Appl Oral Sci 
2005;13:351-355.

8. Gomes AM, Fonseca L, Guedes-Pinto AC. Microbiologic evaluation of biomechanical preparation and of root canals filing past of the primary teeth. Rev Odontopediatr 1997;5:93-101.

9. Ito IY, Matoba Jr F, Paula-Silva FWG, Silva LAB, Leonardo MR, NelsonFilho P. Microbial culture and checkerboard DNA-DNA hybridization assessment of bacteria in root canals of primary teeth pre- and postendodontic therapy with a calcium hydroxide/chlorhexidine paste. Int J Paediatr Dent 2011;21:353-360.

10. Triches TC, Figueiredo LC, Feres M, Freitas SFT, Zimmermann GS, Cordeiro MMR. Microbial profile of root canals of primary teeth with pulp necrosis and periradicular lesion. J Dent Child 2014;81:14-19.

11. Socransky SS, Smith C, Martin L, Paster BJ, Dewhirst FE, Levin AE. "Checkerboard" DNA-DNA hybridization. Biotech 1994;17:788-792.

12. Pazelli LC, Freitas AC, Ito IY, Souza-Gugelmin MCMS, Medeiros AS, Nelson-Filho P. Prevalence of microorganisms in root canals of human deciduous teeth with necrotic pulp and chronic periapical lesions. Pesq Odontol Bras 2003;17:367-371.

13. Ruviére DB, Leonardo MR, Silva LAB, Ito IY, Nelson-Filho P. Assessment of the microbiota in root canals of human primary teeth by checkerboard DNA-DNA hybridization. J Dent Child 2007;74:118-123.

14. Cerqueira DF, Mello-Moura ACV, Santos EM. Cytotoxicity, histopathological, microbiological and clinical aspects of an endodontic iodoform-based paste used in pediatric dentistry: A review. J Clin Pediatr Dent 2007;32:105-110.

15. Amorim LF, Toledo OA, Estrela CR, Decurcio DA, Estrela C. Antimicrobial analysis of different root canal filling pastes used in pediatric dentistry by two experimental methods. Braz Dent J 2006;17:317-322.

16. Gondim JO, Acava-Crusca JS, Valentini SR, Zanelli CF, Spolidorio DMP, Giro EMA. Effect of a calcium hydroxide/chlorhexidine paste as intracanal dressing in human primary teeth with necrotic pulp against Porphyromonas gingivalis and Enterococcus faecalis. Int J Paed Dent 2012;22:116-124

17. Peters LB, Winkelhoff AJ, Wesselink PR. Effects of instrumentation, irrigation and dressing with calcium hydroxide on infection in pulpless teeth with periapical bone lesions. Int Endod J 2002;35:13-21.

18. Kummer TR, Calvo MC, Cordeiro MMR, Vieira RS, Rocha MJCR. Ex vivo study of manual and rotary instrumentation techniques in human primary teeth. Oral Surg, Oral Med, Oral Pathol, Oral Radiol Endod 2008; 105:e84-e92.

19. Beltrame APCA, Triches TC, Sartori N, Bolan M. Electronic determination of root canal working length in primary molar teeth: an in vivo and ex vivo study. Int Endod J 2011;44:402-406.

Received February 25, 2014 Accepted April 19, 2014 